\title{
Manajemen Keterampilan Membaca dan Menulis Mata Pelajaran Bahasa Indonesa di Sekolah Dasar
}

\author{
Murni Yanto \\ Institut Agama Islam Negeri Curup \\ yantomurni.65@gmail.com
}

\begin{abstract}
Abstrak: Artikel ini bertujuan untuk mengetahui pelaksanaan membaca dan menulis siswa kelas 1 Sekolah Dasar Negeri nomor 02 Rejang Lebong. Jenis penelitian yang dilakukan adalah penelitian kuantitatif. Penelitian kuantitatif adalah suatu cara menemukan pengetahuan yang menggunakan berbentuk angka sebagai alat menemukan keterangan. Mengenai apa yang ingin diketahui. Populasi penelitian siswa kelas 1 berjumlah 28 orang. Sample yang digunakan dalam penelitian ini adalah sample purposive, yaitu teknik pertimbangan tertentu. Sample penelitian ini adalah siswa kelas 1 Sekolah Dasar Negeri 02 Rejang Lebong yang berjumlah 14 orang, yang terdiri dari 9 prempuan 5 laki-laki. Pengumpulan data dengan menggunakan angket dan tes. Tes yang digunakan tes tertulis dan tes lisan. Hasil yang diperoleh penelitian ini dilakukan melalui angket diambil kesimpulan bahwa keterampilan membaca dan menulis siswa kelas satu yaitu tinggi dan rendah. Antara variabel $\mathrm{x}$ dan y terdapat korelasi yang kuat atau tinggi. Dengan memperhatikan besarnya $r_{x y}$ yaitu 0,763 yaitu berkisar antara 0,70-0,90. Jadi, dapat disimpulkan hipotesa (Ha) tidak ada pengaruh terhadap membaca dan menulis siswa kelas 1 Rejang Lebong atau hipotesa (Ha) diterima,sedangkan hipotesa (Ho) kemampuan membaca dan menulis atau hipotesa (Ho) ditolak.
\end{abstract}

Kata kunci: Manajemen, Keterampilan Membaca, Menulis

Abstract: This article aimed to find out the implementation of reading and writing grade 1 students at State Elementary School number 02 Rejang Lebong. The type of research conducted is quantitative research. Quantitative research is a way of finding knowledge that uses numeric form as a means of finding information regarding what you want to know. The research population of class 1 students was 28 people. The samples used in this study were purposive samples, namely certain consideration techniques. The sample of this study was class 1 students of Rejang Lebong 02 Elementary School, which consisted of 14 people, consisting of 9 women and 5 men. Data collection using questionnaires and tests. Tests are used written tests and oral tests. The results obtained by this study were conducted through a questionnaire which concluded that the reading and writing skills of first grade students were high and low. Between variables $x$ and $y$ there is a strong or high correlation. With regard to the magnitude of $r_{-} x y$ which is 0.763 , it ranges from 0.70-0.90, so it can be concluded that the hypothesis ( $\mathrm{Ha}$ ) has no effect on reading and writing class 1 Rejang Lebong or hypothesis ( $\mathrm{Ha}$ ) accepted, while the hypothesis (Ho) of reading ability and write or hypothesis (Ho) rejected.

Keywords: Management, Reading Skills, Writing skils 


\section{Pendahuluan}

Pendidikan adalah usaha sadar dan terencana untuk mewujudkan suasana belajar dan proses pembelajaran agar peserta didik secara aktif mengembangkan potensi dirinya untuk memiliki kekuatan spiritual keagamaan, pengendalian diri, kepribadian, kecerdasan, akhlak mulia, serta keterampilan yang diperlukan dirinya, masyarakat, bangsa dan negara. Manajemen diperlukan dalam peningkatan kualitas hidup manusia Indonesia melalui pendidikan menjadi isu strategis untuk meningkat sumber daya manusia. Secara etimologis istilah manajemen berasal dari bahasa Perancis kuno "management" yang berarti seni melaksanakan dan mengatur (Suparlan, 2013).

Di dalam PP RI No. 27 Tahun 1990 tentang Pendidikan Pra-sekolah. Bab I Pasal 1 Ayat (2) dinyatakan bahwa yang dimaksud dengan Taman Kanak-Kanak (TK) adalah salah satu bentuk pendidikan prasekolah yang menyediakan program pendidikan dini bagi anak usia empat tahun sampai memasuki pendidikan dasar (Patmonodewo S. , 2003).

Pembelajaran bahasa anak usia dini diarahkan pada kemampuan berkomunikasi, baik secara lisan maupun tertulis (simbolis). Untuk memahami bahasa simbolis, anak perlu belajar membaca dan menulis. Oleh karena itu, belajar bahasa sering dibedakan menjadi dua, yaitu belajar bahasa untuk komunikasi dan belajar literasi, yaitu membaca dan menulis (Susanto, 2011).

Membaca yaitu melihat serta memahami suatu tulisan atau uraian, melihat dan menilai (tentang situasi), mengucapkan (doa) (Y.S.Chaniago, 1995). Membaca merupakan proses yang kompleks yang melibatkan kedua belahan otak. Anak harus sudah memahami bahasa curah verbal harus baik, mengenal huruf dan arah, dapat mengingat apa yang dilihat dan didengar.

Membaca pada hakikatnya sudah dapat diajarkan pada balita, namun menurut penelitian Glen lebih efektif diberikan pada usia empat tahun daripada usia lima tahun. Bahkan menurutnya, usia tiga tahun lebih mudah daripada empat tahun. Jelasnya, makin kecil makin mudah untuk belajar, namun semakin kecil usianya, akan sangat menuntut kesabaran pada orang tua atau guru yang mengajarkannya (Y.S.Chaniago, Kamus Bahasa Indonesia, 1995). 
Menulis di taman kanak-kanak menurut High Scope Child Observation Record, disebut menulis dini atau menulis awal kegiatan menulis ini mencakup anak mencoba teknik menulis menggunakan lekuk-lekuk dan garis sebagai huruf, meniru tulisan atau meniru huruf-huruf yang dapat dikenal, menulis nama sendiri, menulis beberapa kata atau frasa pendek, menulis frasa atau kalimat bervariasin (Susanto, Perkembangan Anak Usia Dini, 2011).

Dengan membaca dan menulis pada anak bertujuan dapat berkomunikasi dengan baik, dapat menulis, dan mengenal benda-benda yang ada disekitarnya. Siswa juga dapat membaca kata-kata umum atau huruf-huruf yang sudah dikenalnya dan dapat menuliskannya.

Guru bersama orangtualah yang mempunyai tanggung jawab yang besar dalam membimbing dan mendidik anak untuk rajin membaca dan menulis, tentu akan mengantarkan anak pada keberhasilan. Membaca dan menulis merupakan salah satu aktivitas yang paling penting dalam hidup dan dapat dikatakan bahwa semua proses belajar didasarkan pada kemampuan membaca.

Membaca dan menulis merupakan jenis kemampuan berbahasa tulis, seseorang dapat memperoleh ilmu dan pengetahuan serta pengalamanpengalaman baru. Semua yang diperoleh melalui bacaan dan tulisan akan memungkinkan orang mampu mempertinggi daya pikirnya, mempertajam pandangannya dan memperluas wawasannya. Kegiatan membaca merupakan kegiatan yang diperlukan oleh siapapun yang ingin maju dan meningkatkan diri. Keterampilan membaca menulis merupakan salah satu kunci keberhasilan siswa dalam meraih kemajuan dengan kemampuan yang memadai siswa akan lebih mudah menggali informasi dari berbagai sumber tertulis.

Membaca permulaan sebagai kemampuan dasar membaca siswa dan alat bagi siswa untuk mengetahui makna dari isi mata pelajaran yang dipelajarinya di sekolah. Makin cepat siswa dapat membaca makin besar peluang untuk memahami isi makna mata pelajaran di sekolah. Namun pada akhir tahun pelajaran masih juga terdapat siswa yang tidak dapat membaca dan menulis.

Dalam proses belajar mengajar mata pelajaran bahasa Indonesia siswa kurang minat membaca dan menulis karena bagi mereka membaca dan menulis itu sulit. Sehingga kemampuan membaca dan menulisnya 
kurang. Proses belajar di dalam lebih banyak diarahkan guru menerangkan sehingga anak pasif dan anak tidak mempunyai keberanian atau malu ketika disuruh maju kedepan kelas.

Setiap orang tua yang menyekolahkan anaknya menginginkan anaknya berprestasi, pintar dan menjadi orang yang sukses dimasa depan. Namun untuk mencapai hal itu orang tua juga harus memberikan perhatian yang lebih terhadap anak untuk belajar di rumah karena orangtualah yang mempunyai waktu yang lebih banyak untuk membimbing anak dibanding dengan guru disekolah. Di rumah juga waktu bermain anak juga harus dibatasi jadi ada waktu anak untuk belajar di rumah atau mengulang materi yang sudah dipelajari di sekolah.

Atas dasar latar belakang keterampilan membaca dan menulis dalam rumusan masalah ini dituangkan pada pertanyaan penelitian sebagai berikut. Pertama, bagaimana manajemen keterampilan membaca dan menulis siswa kelas I Sekolah Dasar Negeri 02 Rejang Lebong? Kedua, apakah faktor - faktor yang mempengaruhi keterampilan membaca dan menulis siswa kelas I Sekolah Dasar Negeri 02 Rejang Lebong?

Adapun tujuan dilaksanakannya penelitian ini adalah (1) untuk mengetahui keterampilan membaca dan menulis siswa Kelas I Sekolah Dasar Negeri02 Rejang Lebong. (2) Untuk mengetahui faktor-faktor penyebab kurangnya minat belajar siswa Kelas I Sekolah Dasar Negeri 02 Rejang Lebong. (3) Mengembangkan keterampilan membaca dan menulis siswa Kelas I Sekolah Dasar Negeri 02 Rejang Lebong.

\section{Hakikat Membaca}

Membaca adalah suatu proses yang dilakukan serta di pergunakan oleh pembaca untuk memperoleh pesan yang hendak di sampaikan oleh penulis melalui media kata-kata atau bahasa tulis. Suatu proses yang menuntut agar kelompok kata yang merupakan suatu kesatuan akan terlihat dalam suatu pandangan sekilas dan makna kata-kata secara individual akan dapat diketahui (Tarigan H. G., 2008).

Membaca merupakan kemampuan yang harus dimiliki oleh semua anak karena melalui membaca anak dapat belajar banyak tentang berbagai bidang studi. Kemampuan membaca merupakan dasar untuk menguasai berbagai bidang studi (Aburrahman, 2012). 
Membaca dini ialah membaca yang diajarkan secara terprogram kepada anak sekolah. Program ini menumpukkan perhatian pada perkataan-perkataan utuh, bermakna dalam konteks pribadi anak-anak dan bahan-bahan yang diberikan melalui permainan dan kegiatan yang menarik sebagai perantaraan pembelajaran. Sejumlah penelitian menunjukkan bahwa anak yang memahami kata yang diucapkannya lebih siap sekolah daripada anak yang tidak. Mereka mengerti bahwa sekolah adalah untuk salah satunya belajar membaca (Suyadi, 2014).

Suyanto mengatakan bahwa dahulu guru mengajar anak mengenal huruf dengan cara menunjukkan huruf dan mengucapkan bunyinya. Misalnya, guru menunjukkan huruf a sambil berkata $a$; kemudian $b$ dibaca $b e$. Demikian seterusnya yang dilakukan guru hingga membentuk gandengan huruf yang lebih panjang, seperti babe dan bobo. Cara belajar seperti itu dikenal dengan istilah pholic, berasal dari kata fonem yang berarti bunyi huruf atau kata.

Liberman, et al. Dalam suyanto menjelaskan bahwa mengajarkan bahasa dengan cara yang berbeda seperti yang diatas. Ia memberikan suatu kata kepada anak, lalu anak disuruh mengidentifikasi suara apa saja yang terdapat pada kata ini. Misalnya ia memberi kata bat lalu bertanya berapa bunyi yang kamu dengar dari kata ini? Anak disuruh mengetuk meja dengan kayu sesuai dengan jumlah bunyi yang ia dengar dari kata tersebut. Hasil penelitiannya menunjukkan bahwa seluruh siswa kelas 1 sekolah dasar mampu dengan benar mengidentifikasi jumlah bunyi dari kata yang diberikan, dan $50 \%$ anak taman kanak-kanak dan kelompok bermain menunjukkan kemampuan tersebut (Susanto, Perkembangan Anak Usia Dini, 2011).

Bertolak dari definisi di atas bahwa membaca dapat disimpulkan merupakan aktivitas kompleks yang mencakup fisik dan mental.

a. Tujuan membaca

Tujuan utama dalam membaca adalah untuk mencari serta memperoleh informasi, mencakup isi, memahami makna bacaan. Makna, arti (meaning) erat sekali berhubungan dengan maksud tujuan, atau intensif kita dalam membaca. 
1) Membaca untuk menemukan atau mengetahui penemuan-penemuan yang telah dilakukan oleh tokoh; apa-apa yang telah dibuat oleh tokoh. Membaca seperti itu disebut membaca untuk memperoleh perincian-perincian atau fakta-fakta.

2) Membaca untuk memperoleh ide-ide utama.

3) Membaca untuk mengetahui urutan atau susunan, organisasi cerita.

4) Membaca untuk menyimpulkan.

5) Membaca untuk mengelompokkan, membaca untuk mengklasifikasi.

6) Membaca menilai, membaca mengevaluasi.

7) Membaca untuk membandingkan atau pertentangan (Tarigan H. G., Membaca Suatu Keterampilan Berbahasa, 2008).

Jadi dapat disimpulkan tujuan membaca adalah tahap persiapan untuk membaca, baru mengenal huruf-huruf dan bunyinya, kemudian dilatih terus menerus agar mampu membaca dengan baik.

\section{Faktor-faktor yang Mempengaruhi Keterampilan Membaca}

Menurut Sabarti Akhaidah faktor kemampuan membaca:

a. Motivasi

Artinya bahwa motivasi merupakan faktor yang cukup sering gagal karena lemahnya motivasi.

b. Lingkungan Keluarga

Artinya orang tua memiliki kesadaran akan pentingnya kemampuan membaca agar anak - anak di beri kesempatan untuk belajar membaca.

c. Bahan Bacaan

Artinya bahan bacaan mempengaruhi anak maupun kemampuannnya memahami bahan bacaan harus di simpulkan dengan kondisi dan kebutuhan anak jangan terlalu sulit dan terlalu mudah (Sabarti, 1991).

\section{Keterampilan Menulis}

Menulis adalah suatu aktivitas kompleks, yang mencakup gerakan lengan, tangan, jari, dan mata secara terintegrasi. Menulis merupakan 
penggambaran visual tentang pikiran, perasaan, dan ide dengan menggunakan simbol-simbol sistem bahasa penulisnya untuk keperluan komunikasi atau mencatat (Abdurahman, 2012).

Menulis ialah menurunkan atau menuliskan lambang-lambang grafik yang menggambarkan suatu bahasa yang di pahami oleh seseorang, sehingga orang lain dapat membaca lambang-lambang grafik tersebut kalau mereka memahami bahasa dan gambaran grafik tersebut. Menulis merupakan suatu representasi bagian dari kesatuan-kesatuan ekspresi bahasa.

Kegiatan menulis untuk anak usia taman kanak-kanak lebih menekankan pada kegiatan mencurahkan perasaan, gagasan atau ide-ide melalui simbol-simbol tertulis dengan cara bebas atau tidak ide-ide melalui simbol-simbol tertulis dengan cara bebas atau tidak terikat pada kaidah-kaidah penulisan formal (Susanto, Perkembangan Anak Usia Dini, 2011).

Berkenaan dengan keterampilan menulis adalah pengembangan kemampuan agar anak siap untuk belajar menulis. Dan untuk itulah maka upaya pengembangan motorik halus dilakukan secara intensif. Perkembangan anak pada motorik halusnya yang semakin meningkat membuat anak mampu menggambar garis lurus, garis tegak, garis lengkung, lingkaran dan sebagainya, yang merupakan dasar untuk menggembangkan kemampuan menulis.

Anak perlu melalui tahapan perkembangan sebelum mereka menulis kalimat dan belajar kata-kata. Menurut Brown terdapat empat tahapan menulis, yaitu: (Susanto, Perkembangan Anak Usia Dini, Jakarta).

a. Tahap pertama, pre communicative writing, pada tahap ini anak belajar bahwa huruf-huruf itu membentuk kata-kata untuk keperluan komunikasi. Anak memperhatikan orang tua atau saudara-saudaranya membaca dan menulis sekalipun anak belum menghubungkan huruf dan bunyi. Anak akan tetap saja menulis sekalipun orang tua menganggapnya main-main, sebab hal ini merupakan upaya anak untuk berkomunikasi melalui tulisan sekalipun tidak dipahami orang lain.

b. Tahap kedua, semphonic writing, tahap ini anak mulai memahami huruf, bunyi dengan konsonan dalam posisinya sebuah kata. 
c. Tahap ketiga, phonic writing, tahap ini amak mulai mengeja bunyi kata menurut struktur kata.

d. Tahap keempat, transtitional writing, tahap ini merupakan tahapan transisi di mana anak mulai mengikuti aturan-aturan untuk standar ejaan.

\section{Metode Penelitian}

Penelitian kuantitatif adalah suatu proses menemukan pengetahuan yang menggunakan data berupa angka sebagai alat menemukan keterangan mengenai apa yang ingin kita ketahui (Sugiono, 2012). Kegiatan sampling dilakukan atas populasi yang dibatasi wilayah geografis dan kronologinya (Purwanto, 2011). Penelitian dilaksanakan di SDN 02 Curup.

A. Populasi dan Sampel Penelitian

a) Populasi

Populasi berasal dari bahasa Inggris Population yang berarti jumlah penduduk (Sadily, 2005).

Untuk lebih memperjelas pemahaman terdapat beberapa pengertian populasi menurut para ahli:

1) Menurut Burhan Bungin, populasi penelitian merupakan keseluruhan (universum) dari objek penelitian yang dapat berupa manusia, hewan tumbuhan-tumbuhan, udara, segala, nilai, peristiwa, sikap hidup dan sebagainya, sehingga objekobjek ini dapat menjadi sumber data penelitian (Bungin, 2006).

2) Suharsimi mengungkapkan bahwa populasi adalah keseluruhan subjek penelitian. (Arikunto, 2007).

b) Sampel

Sampel adalah bagian dari populasi yang akan diteliti secara mendalam (Moh. Kasiram, 2008). Dalam penelitian ini yang dijadikan sampel adalah 14 siswa. 
B. Teknik Pengumpulan Data

Data dalam penelitian ini, maka alat pengumpulan data:

1. Angket

Angket adalah kumpulan dari pertanyaan yang diajukan secara tertulis kepada seseorang (yang dalam hal ini disebut responden), dan cara menjawab juga dilakukan dengan tertulis.

2. Tes

Tes adalah alat ukur yang diberikan kepada individu untuk mendapatkan jawaban-jawaban yang diharapkan baik secara tertulis atau secara lisan atau secara perbuatan (Ibrahim, 2004).

3. Dokumentasi

Dokumentasi yaitu mencari data mengenai hal-hal atau variabel yang berupa catatan, buku, transkip, surat kabar, majalah, prasasti, notulen, agenda dan sebagainya.

\section{Jenis dan Sumber Data}

1. Jenis Data

Data yang diperoleh dalam penelitian ini ada dua macam yaitu daya primer dan data sekunder.

a) Data primer adalah data yang dihimpun atau diambil langsung oleh peneliti (Riduan, 2002). Data primer diambil dari berdasarkan hasil pengumpulan data melalui tes yang diberikan.

b) Data sekunder adalah data yang diperoleh dari tangan yang kedua. Adapun data biasanya telah terbentuk dalam dokumen-dokumen, buku-buku catatan maupun sumber lain yang ada sangkut pautnya dalam penelitian.

2. Sumber Data

Data yang bersumber dari responden yang terdiri dari siswa-siswi SDN 02 Curup.

3. Analisis Data

Analisis yang digunakan rumus: Rumus korelasi product moment pearson (Sudijono, 2012).

$$
r_{x y}=\frac{N \Sigma X Y-(\Sigma X)(\Sigma Y)}{\sqrt{\left.\left\{N \Sigma X^{2}-(\Sigma X)^{2}\right\} N \Sigma Y^{2}-(\Sigma Y)^{2}\right\}}}
$$

Keterangan: 


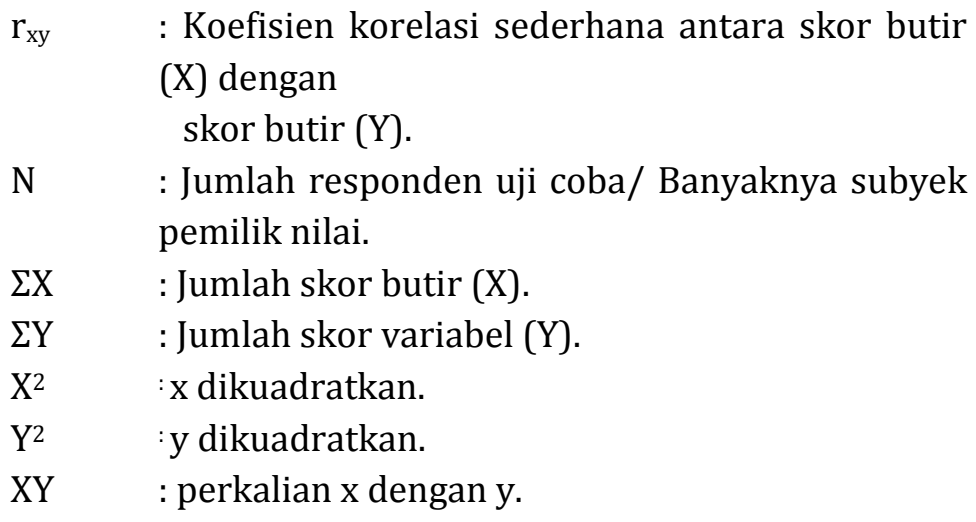

y terdapat korelasi yang kuat atau tinggi. Dengan memperhatikan besarnya $r_{x y}$ yaitu 0,763 yaitu berkisar antara $0,70-0,90$. Terdapat pengaruh yang signifikan pendidikan.

\section{Daftar Rujukan}

Aburrahman, M. (2012). Anak Berkesulitan Belajar. Jakarta: Rineka Cipta.

Arikunto, S. (2007). Manajemen Penelitian. Jakarta: rineka Cipta.

Bungin, B. (2006). Komunikasi, Ekonomi, dan Kebijakan Publik Serta ilmu-ilmu sosial lainnya. Jakarta: Kencana.

Ibrahim, N. S. (2004). Penelitian dan Penilaian Pendidikan. Bandung: Sinar Baru Algensindo.

Moh.Kasiram. (2008). Metode Penelitian Kuantitatif-kualitatif. Malang: UIN Malang.

Patmonodewo, S. (2003). Pendidikan Anak Prasekolah. Jakarta: Rineka Cipta.

Purwanto. (2011). Statistika Untuk Penelitian. Yogyakarta: Pustaka Pelajar.

Riduan. (2002). Skala Pengukuran Variabel-variabel Penelitian. Bandung: Pustaka Setia.

Sabarti, A. (1991). Bahasa Indonesia. Jakarta: Depdikbud.

Sadily, J. M. (2005). Kamus Inggris Idonesia. Jakarta: Gramedia Pustaka Utama. 
Sudijono, A. (2012). Pengantar Statistik pendidikan. Jakarta: Raja Grafindo Persada.

Sugiono. (2012). Metode Penelitian Kualitatif kualitatif dan R\&D . 2012: Alfabeta.

Suparlan. (2013). Manajemen Berbasis Sekolah Dari Teori Sampai Dengan Praktik. Jakarta: PT.Bumi Aksara.

Susanto, A. (2011). Perkembangan Anak Usia Dini. Jakarta: Kencana.

Suyadi. (2014). Pembelajaran Anak Usia Dini. Bandung: Remaja Rosdakarya.

Tarigan, H. G. (2008). Membaca Suatu Keterampilan Berbahasa. Bandung: Angkasa.

Y.S.Chaniago, A. (1995). Kamus Bahasa Indonesia. Jakarta: Pustaka Setia. 